\title{
外部放射線治療における腫瘍位置確認用金マーカからの 散乱線による人体への影響の検討
}

\author{
羽原幸作 ${ }^{1)}$ ・下郷智弘 ${ }^{2)}$ ・青山裕一 3$)$ - 林 直樹 ${ }^{4)}$ ・安井啓祐 ${ }^{5)}$
}

松浦寛司 ${ }^{6)}$ ・古川隆志 ${ }^{1)}$ ・ 川浪亮太 ${ }^{3)}$ ・ 小幡康範 ${ }^{2)}$

\author{
論文受付 \\ 2011 年 1 月26日 \\ 論文受理 \\ 2011 年 7 月20日 \\ Code No. 431
}

1 ) 広島赤十字・原爆病院放射線科部

2)名古屋大学大学院医学系研究科

3) 名古屋大学医学部附属病院放射線部

4)藤田保健衛生大学医療科学部放射線学科

5)名古屋市健康福祉局

6)広島市立広島市民病院放射線科
絔

近年，治療装置および周辺機器の進歩は目覚まし

く，体幹部における高精度な放射線治療が盛んに行 われるようになってきた，その中のひとつに定位放射 線治療 ${ }^{1)}$ がある。

体幹部における定位放射線治療は生理的な呼吸性 移動および蔵器の移動があるため, 再現性のある位 置精度を保持することが困難である。また，その照
射方法および位置精度の保持は施設によりさまざま な取り組みが行われているがまだまだ確立していな い部分がある。1998 年には北海道大学において 4 次 元放射線治療と呼ばれる動体追跡放射線治療 ${ }^{2}$ が開 発され，臨床応用されるようになった。動体追跡放 射線治療では, 目的とする腫瘍の近傍に金マーカを 挿入し，その位置や動きをX 線透視装置にてリアル タイムに確認しながら照射が行われる.

\section{Dosimetric Perturbation due to Scattered Rays Released by a Gold Marker Used for Tumor Tracking in External Radiotherapy}

Kosaku Habara,,) Tomohiro Shimozato,, ${ }^{2)}$ Yuichi Aoyama, ${ }^{3)}$ Naoki Hayashi, ${ }^{4)}$ Keisuke Yasui, $\left.{ }^{5}\right)$ Kanji Matsuura, $\left.{ }^{6}\right)$ Takashi Furukawa,1) Ryota Kawanami, ${ }^{3)}$ and Yasunori Obata ${ }^{2)}$

1 ) Division of Radiology, Hiroshima Red Cross Hospital \& Atomic-bomb Survivors Hospital

2) Department of Radiological Sciences, Graduate School of Medicine, Nagoya University

3) Department of Radiological Technology, Nagoya University Hospital

4) Faculty of Radiological Technology, School of Health Science, Fujita Health University

5) Health \& Welfare Bureau, City of Nagoya

6) Department of Radiology, Hiroshima City Hospital

Received January 26, 2011; Revision accepted July 20, 2011; Code No. 431

\section{Summary}

Image-guided radiation therapy using a gold marker-based tumor tracking technique provides precise patient setup and monitoring. However, the marker consists of high-Z material, and the resulting scattered rays tend to have adverse effects on the dose distribution of radiotherapy. The purpose of this study was to evaluate the dosimetric perturbation due to the use of a gold marker for radiotherapy in the lungs. The relative dose distributions were compared with film measurement, Monte Carlo simulation, and XiO calculation with the multi grid superposition algorithm using two types of virtual lung phantoms, which were composed of tough water phantoms, tough lung phantoms, cork boards, and a 2.0-mm-diameter gold ball. No dose increase and decrease in the vicinity of the gold ball was seen in the $\mathrm{XiO}$ calculations, although it was seen in the film measurements and the Monte Carlo simulation. The dose perturbation due to a gold marker cannot be evaluated using $\mathrm{XiO}$ calculation with the superposition algorithm when the tumor is near a gold marker (especially within $0.5 \mathrm{~cm}$ ). To rule out the presence of such dose perturbations due to a gold marker, the distance between the gold marker and the tumor must therefore be greater than $0.5 \mathrm{~cm}$.

Key words: tumor tracking, gold marker, Monte Carlo simulation, superposition algorithm, dose perturbation 


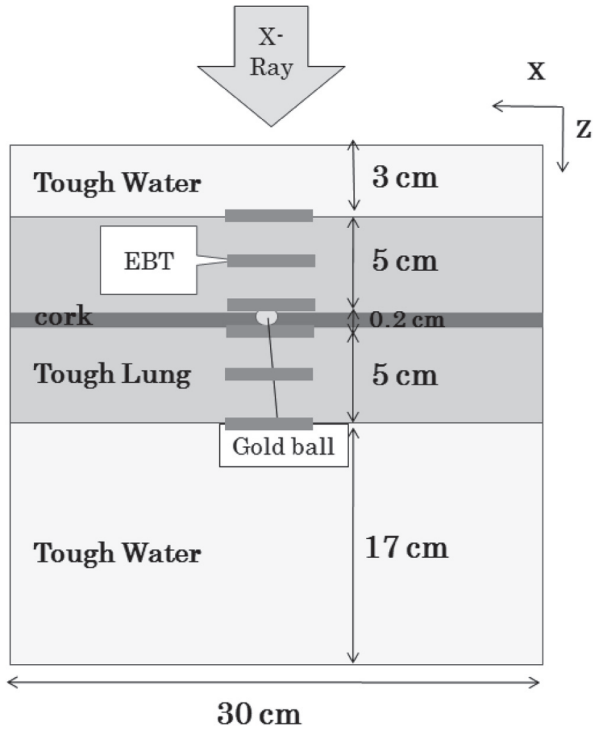

Fig. 1 Schematic illustration of a virtual lung phantom (model 1).

金マーカによる位置監視では, 腫瘍の位置が高精 度に同定できるが, 放射線治療計画装置(radiotherapy treatment planning system; RTPS)による線量計算では 金属などの高原子番号・高密度物質の存在下で線量 が正しく計算されないことが報告されている こで本研究ではフィルム法による実測, モンテカルロ 計算, RTPSを用いて相対線量分布を取得し, 比較 を行うことで金マーカからの散乱線による人体への影 響を検討した。

\section{1. 方 法}

\section{1-1 肺野内における金マーカの線量分布への影響： 1 ビーム}

1-1-1 Radiochromic Film を用いた線量分布測定

治療用フィルムを用いて線量分布を取得するた め, 名古屋大学医学部附属病院の医療用加速器 LINAC（Varian Clinac 21 EX)を使用して測定を行っ た。まず，線量を濃度に変換する校正曲線を取得す るため, 30×30×30 cm $\mathrm{cm}^{3}$ のタフウォータファントム (京 都科学)を配置し，ファントム表面から深さ $10 \mathrm{~cm}$ の ところに同じロット番号の Radiochromic film (Gafchromic film EBT (ISP. Inc); 以下, EBT) を挟 むように配置した ${ }^{5,6)}$ 。測定は $10 \mathrm{MV}$ の X 線で行い, 照射野は $10 \times 10 \mathrm{~cm}^{2}$, SAD は $100 \mathrm{~cm}(\mathrm{SSD}$ は $90 \mathrm{~cm})$ として $0 \mathrm{MU}$ から $400 \mathrm{MU}$ まで 13 点の線量を測定し た。ここで $1 \mathrm{MU}$ は最大深において $1 \mathrm{cGy}$ となる值で ある. 濃度対線量の校正用の電離箱線量計には PTW 社製の $0.6 \mathrm{cc}$ ファーマ型電離箱(Type 30013)を用いた。

次にタフウォータファントム, タフラングファント ム (京都科学), コルク板(神戸コルク株式会社), 直
径 $2 \mathrm{~mm}$ の金球(栄進)で構成された仮想肺ファント ムを Fig. 1 に示す。また, Table 1 に仮想肺ファント ムの構成, 物質の密度, 相対電子密度を示す。線量 分布を取得するために EBTをファントム表面から深 さ $3 \mathrm{~cm}, 5 \mathrm{~cm}, 8 \mathrm{~cm}, 8.2 \mathrm{~cm}, 10.28 \mathrm{~cm}, 15.3 \mathrm{~cm}$ の 6 点に挟むように配置した。ここで $5 \mathrm{~cm}$ は相対線量の 基準となる深さ, $8 \mathrm{~cm}$ は金球透過直前の深さ, $8.2 \mathrm{~cm}$ は金球透過直後の深さである。照射野を $5 \times 5 \mathrm{~cm}^{2}$,

$\mathrm{SSD}$ を $100 \mathrm{~cm}$ とした。 また，濃度值がある程度出力さ れ，かつ飽和しないようにするため MU 值を $250 \mathrm{MU}$ とし, 線量率を $300 \mathrm{MU} / \mathrm{min} に$ 設定して照射を 行った。測定に用いた全ての EBTはフラットベッ ドスキャナ(EPSON Offirio ES 10000G)と DD-system (Version 9.0.0, R-TECH. Inc)を用いて解析を行った.

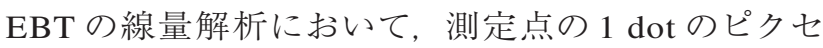
ルサイズは $0.017 \mathrm{~cm}$ である.

EBT を利用した測定においては，感度のばらつ きによる線量誤差が5\%程度であると報告されてい る5)。本研究では実測のデータである EBTを基準と してその他との比較を行った，EBTに対する誤差率 は以下の式で表わすことができる.

difference[1] $=\frac{D_{\mathrm{EGS} 5}-D_{\text {measurement }}}{D_{\text {measurement }}} \times 100[\%]$

difference[2] $=\frac{D_{\text {Xio }}-D_{\text {measurement }}}{D_{\text {measurement }}} \times 100[\%]$

$D_{\mathrm{EGS5}}, D_{\text {measurement }}, D_{\mathrm{XiO}}$ はそれぞれ(Electron Gamma Shower Version 5; EGS5)の計算結果, EBT の測定結 果, 放射線治療計画装置 $\mathrm{XiO}(\mathrm{CMS}$. Inc)の計算結果 の相対線量值である。 difference[1] はEBTに対する EGS5の誤差率を表し, difference[2]はEBTに対す る XiOの誤差率を表している.

\section{1-1-2 EGS5 を用いたモンテカルロ計算}

モンテカルロ計算には EGS5 を用いた。 まずシミュ レーションの信頼性を検証するために $30 \times 30 \times 30 \mathrm{~cm}^{3}$ の水ファントム中における EGS5 と電離箱による実測 の percent depth dose (PDD)の比較を行った．入射粒 子は $10 \mathrm{MV}$ の制動 $\mathrm{X}$ 線とし, 入射光子のエネルギー スペクトルは Sheikh-Bagheri らのデータを使用した7). 照射野は $5 \times 5 \mathrm{~cm}^{2}$, source surface distance (SSD) は $100 \mathrm{~cm}$ とした。また，本研究におけるすべての 計算において電子と光子の輸送を停止するための カットオフエネルギーである electron cut off energy (ECUT)と photon cut off energy（PCUT)をそれぞれ $521 \mathrm{keV}, 10 \mathrm{keV}$ とした。電子については静止質量エ ネルギーを含む。その結果, ビルドアップ領域を除き 
Table 1 Compositions of the materials of the virtual lung phantom

\begin{tabular}{llcc}
\hline \hline \multicolumn{1}{c}{ Materials } & \multicolumn{1}{c}{ Element composition (\%) } & $\begin{array}{c}\text { Densit } \\
{\left[\mathrm{g} / \mathrm{cm}^{3}\right]}\end{array}$ & $\begin{array}{c}\text { Relative electron } \\
\text { density of water }\end{array}$ \\
\hline Water & $\mathrm{H}(33.33), \mathrm{O}(66.67)$ & 1.0 & 1.0 \\
Tough water & $\mathrm{H}(8.20), \mathrm{C}(66.26), \mathrm{N}(2.20), \mathrm{O}(20.71), \mathrm{Cl}(0.37), \mathrm{Ca}(2.27)$ & 1.018 & 0.994 \\
Tough lung & $\mathrm{H}(7.00), \mathrm{C}(50.20), \mathrm{O}(35.10), \mathrm{P}(0.10), \mathrm{Cl}(1.00), \mathrm{Al}(1.50), \mathrm{Si}(5.00)$ & 0.32 & 0.29 \\
Cork & $\mathrm{H}(6.78), \mathrm{C}(53.87), \mathrm{O}(39.35)$ & 0.3 & 0.273 \\
Gold ball & $\mathrm{Au}(100.0)$ & 19.3 & 14.0 \\
\hline
\end{tabular}

EGS5 と実測は誤差率 $\pm 1.9 \%$ 以内の精度で一致した。

$$
\text { シミュレーションのジオメトリはフィルムによる実 }
$$
測とモンテカルロ計算を比較するために EBT を除い て実測の体系をできる限り正確に再現した。水と EBT の構成が近いため, EBT の厚み幅に合わせて水 を用いた。金球はグリッド状にファントムを区切った 体形内に更に球体として設置している。 入射粒子は $10 \mathrm{MV}$ の制動 $\mathrm{X}$ 線とし，照射野は $5 \times 5 \mathrm{~cm}^{2} ， \mathrm{SSD}$ は $100 \mathrm{~cm}$ とした.

EBTに沈着したエネルギーを取得するため，まず ビーム中心軸上において縦 $0.2 \mathrm{~cm}$, 横 $0.2 \mathrm{~cm}$, 深さ $0.1 \mathrm{~cm}$ の領域(ボクセル)を深さ方向に並べ，それぞれ のボクセルにおけるデータを取得した，ただし，深さ 方向に対して金球透過前後 $1 \mathrm{~cm}$ は $0.05 \mathrm{~cm}$ 厚とした. 次にビーム中心軸に対し垂直方向において縦 $0.2 \mathrm{~cm}$, 横 $0.1 \mathrm{~cm}$, 深さ $0.0234 \mathrm{~cm}$ の領域(ボクセル)を横方 向に並べ，それぞれのボクセルにおけるデータを取 得した。深さはEBTの厚みに合わせて設定した。た だし，横方向に対して金球間距離は $0.2 \mathrm{~cm}$ 厚の場合 と $0.016 \mathrm{~cm}$ 厚の場合の 2 パターンで計算を行った. シミュレーションの結果に対する統計誤差は $50 \%$ 以 上の線量域において $1 \%$ 以下となるように粒子数を $2 \times 10^{9}$ 個に設定した。

\section{1-1-3 放射線治療計画装置 XiO による計算}

放射線治療計画装置 $\mathrm{XiO}(\mathrm{CMS}$. Inc)による線量分 布計算を行うために, computed tomography $(\mathrm{CT})$ シ ミュレータを用いて仮想肺ファントムの撮影，再構成 を行った。治療計画用 CT 装置は東芝メディカル社 製のAsteionを使用した。 $\mathrm{XiO}$ の計算アルゴリズムに はPencil 法, Clarkson 法, Superposition 法などがあ るが, 今回不均質組織に対する計算がより優れてい るSuperposition 法を用いた。計算グリッドサイズは $0.1 \times 0.1 \times 0.1 \mathrm{~cm}^{3}$ とし，ピクセル毎に不均質補正を行っ た(Fig. 2).

$\mathrm{XiO}$ では CT 值を相対電子密度に変換するテーブ ルが必要となる。放射線治療で行われる低密度の肺 野から高密度の骨までを考慮したXiOの CT 值 - 相 対電子密度変換テーブルの範囲は 0.3 から 1.8 までと

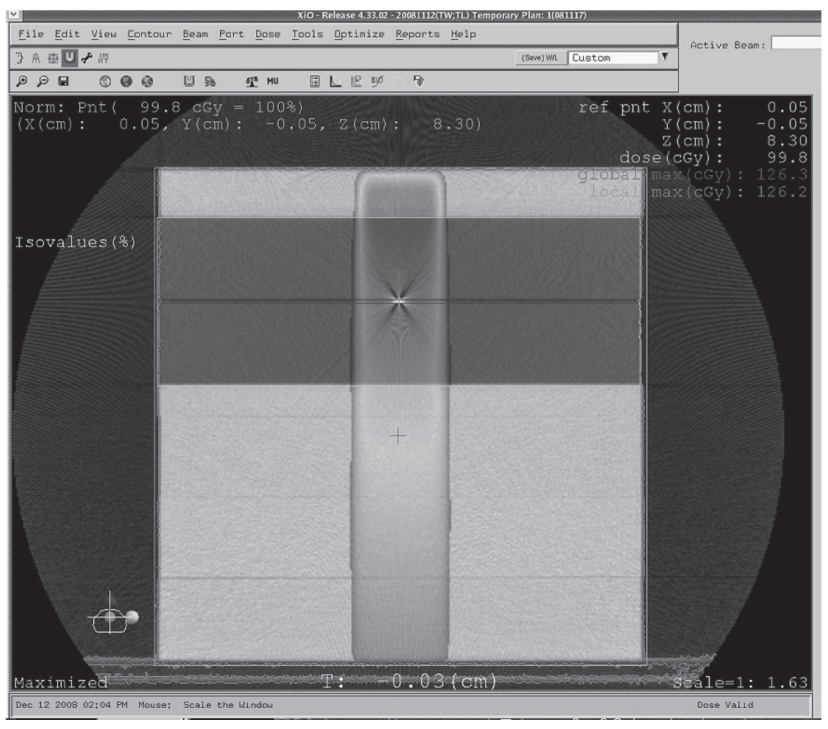

Fig. 2 Dose distributions calculated using the superposition algorithm.

なっている．金球の相対電子密度は 14.0 とテーブルの 範囲を超えてしまうが，XiO で高密度を含む CT 值 相対電子密度変換テーブルを用いた場合, 離散化処 理によって水付近の相対電子密度が粗くなってしま い計算のずれが生じる。そのため, 臨床の条件に合 わせてフィルムによる実測, モンテカルロ計算の結果 との比較を行った。また金属アーチファクトも考慮し て XiO 上で virtual phantom を作成し，金球の相対電 子密度も 14.0 に設定した。そして non virtual phantom と同様の条件で計算を行い, 比較した。

\section{1-2 肺野内における金マーカの線量分布への影響 : 8 ビーム}

多方向からの照射における線量分布の比較を行う ため, EGS5 と XiOを用いて新たに Fig. 3 に示すよう なシミュレーションのジオメトリを作成した. ジオメ トリは水, タフラング, 直径 $2 \mathrm{~mm}$ の金球で構成され た一辺 $16 \mathrm{~cm}$ の立方体ファントムを想定して作成し た。 入射粒子は $10 \mathrm{MV}$ の制動 X 線とし，照射野は $5 \times 5 \mathrm{~cm}^{2}$, source axis distance $(\mathrm{SAD})$ は $100 \mathrm{~cm}$ とし 

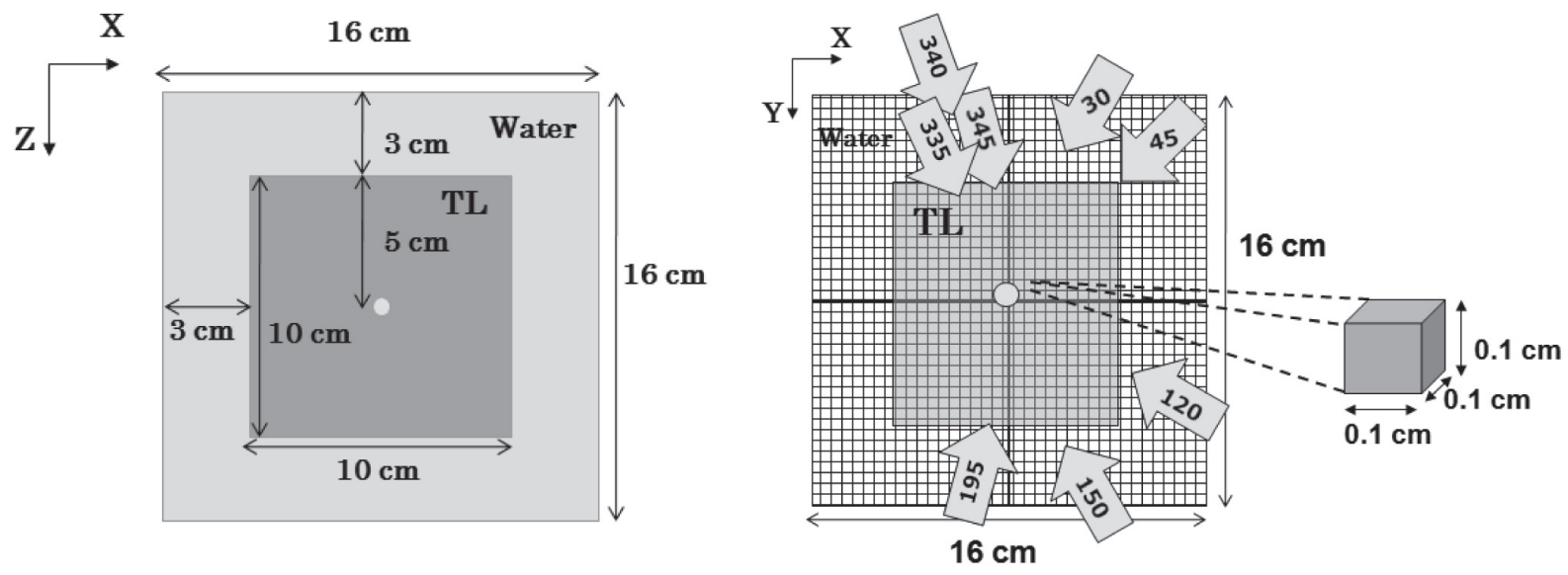

Fig. 3 Schematic geometry of a virtual lung phantom (model 2 ) for (a) xz plane and (b) xy plane.

た. 金球の中心をアイソセンタとしてガントリ角度 $30^{\circ}, 45^{\circ}, 120^{\circ}, 150^{\circ}, 195^{\circ}, 335^{\circ}, 340^{\circ}, 345^{\circ}$ の 8 方 向からの照射プランを作成した。ガントリ角度につい ては臨床における一例の肺定位照射のガントリ角度 を参照にした。また, 沈着エネルギーを取得するた め, $x y$ 平面上のボクセルを縦 $0.1 \mathrm{~cm}$, 横 $0.1 \mathrm{~cm}$ 間隔 に区切り, 金球中心を深さ $0 \mathrm{~cm}$ として深さ $\pm 0.25 \mathrm{~cm}$ 以内のデータを取得した。

本研究では EGS5 と XiO の計算結果を比較するた め, 各深さにおける照射野内の平坦化領域で EGS5 を基準として相対線量化を行った. EGS5 に対する $\mathrm{XiO}$ の誤差率は以下の式で表わすことができる.

$$
\text { difference[3] }=\frac{D_{\mathrm{Xio}}-D_{\mathrm{EGS} 5}}{D_{\mathrm{EGS} 5}} \times 100[\%]
$$

\section{2. 結果}

\section{2-1 肺野内における金マーカの線量分布への影響 :}

$$
1 \text { ビーム }
$$

2-1-1 ビーム軸に対して平行な方向における比較

フィルムによる実測において, DD-systemにより作 成した線量対濃度の校正曲線を Fig. 4 に示す. 本研 究では, 線量分布を取得するために用いた EBT は全 てこの校正曲線をもとに濃度から線量へ変換した。

ビーム軸に対して平行な方向においてフィルムによ る実測, モンテカルロ計算, RTPS による計算の結果 を比較したものを Fig. 5 に示す. EBT による 6 つの測 定点の中で最も線量が安定している箇所は深さ $5 \mathrm{~cm}$ の点であった。そこで本研究では，ファントム表面か ら深さ $5 \mathrm{~cm}$ のころで EBTを基準として相対線量 化を行った，Fig. 5 を見ると, EGS5 と EBT の結果は 金球透過直後の点を除いてよい一致を示している。

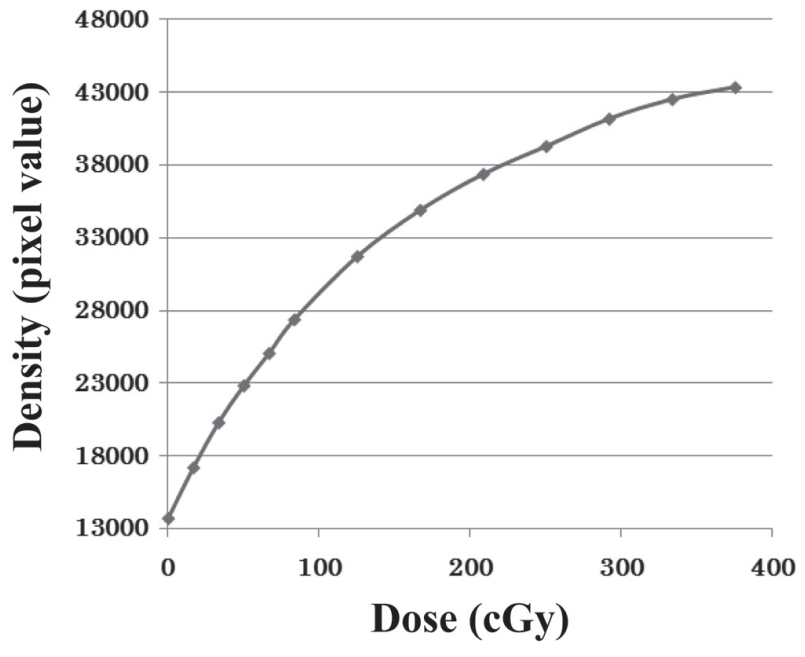

Fig. 4 Density-dose conversion curve for EBT film.

一方で, $\mathrm{XiO}$ は金球透過前後で線量の変化が見られ ない結果となった。各深さにおいて EBTに対する差 を Table 2 にまとめた. EGS5 では金球透過直後の $8.2 \mathrm{~cm}$ 深で $7.0 \%$ 差異が生じたが, その他では EBTと良い一致を示した。金球透過直前における $\mathrm{XiO}$ の計算結果は EBT に対して $20.8 \%$ の過小評価と なり，また金球透過直後における計算結果はEBTに 対して $16.4 \%$ の過大評価となった。

Superposition 法により計算した virtual phantom と non virtual phantom の計算結果の比較を Fig. 6 に示 す.Fig. 6 を見ると全体的によく一致しており，金属 アーチファクトによる影響は見られなかった。

2-1-2 ビーム軸に対して垂直な方向における比較 ビーム軸に対して垂直な方向においてフィルムによ る実測，モンテカルロ計算，RTPSによる計算の結果 


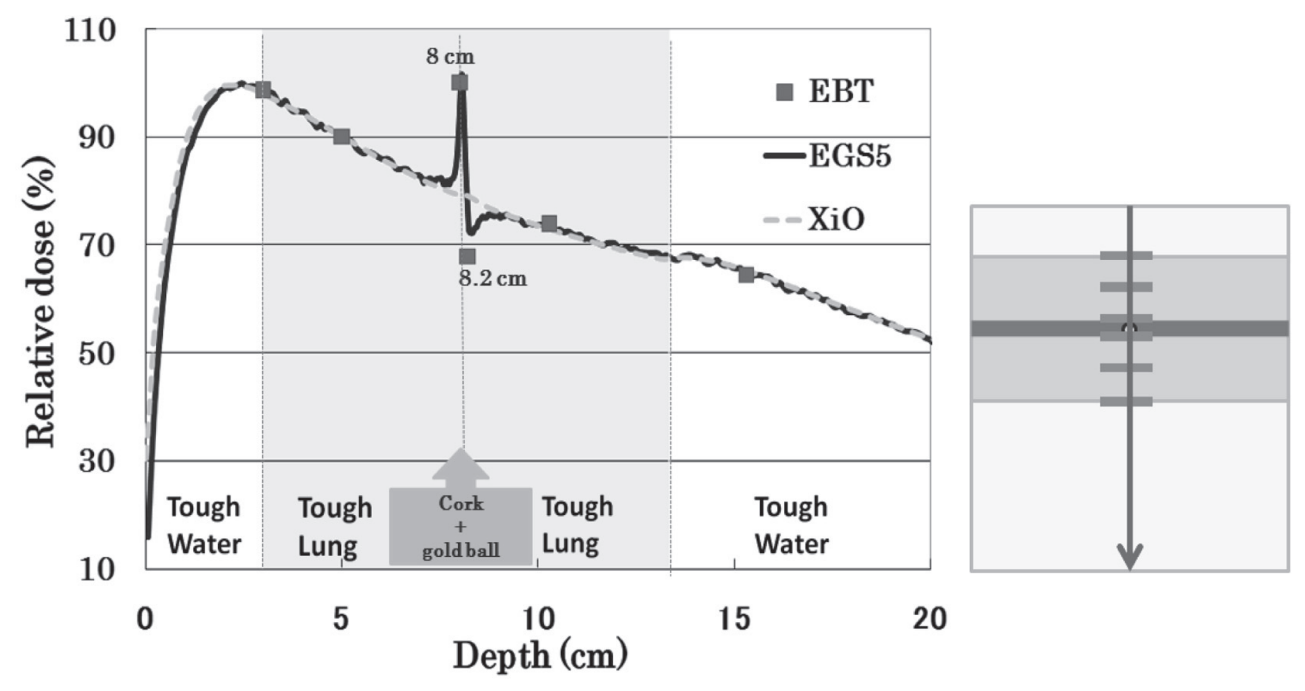

Fig. 5 Comparison among film measurement (EBT), the MC simulation (EGS5), and RTPS calculation $(\mathrm{XiO})$ along the beam axis.

Table 2 Difference between EGS5 and XiO based on EBT at each depth

\begin{tabular}{lcccccc}
\hline \hline Depth (cm) & 3 & 5 & 8 & 8.2 & 10.3 & 15.3 \\
difference [1] (\%) & -0.3 & 0 & -3.1 & 7 & -1.1 & 0.4 \\
difference [2] (\%) & -0.7 & 0 & -20.8 & 16.4 & -1.4 & 1.2 \\
\hline
\end{tabular}

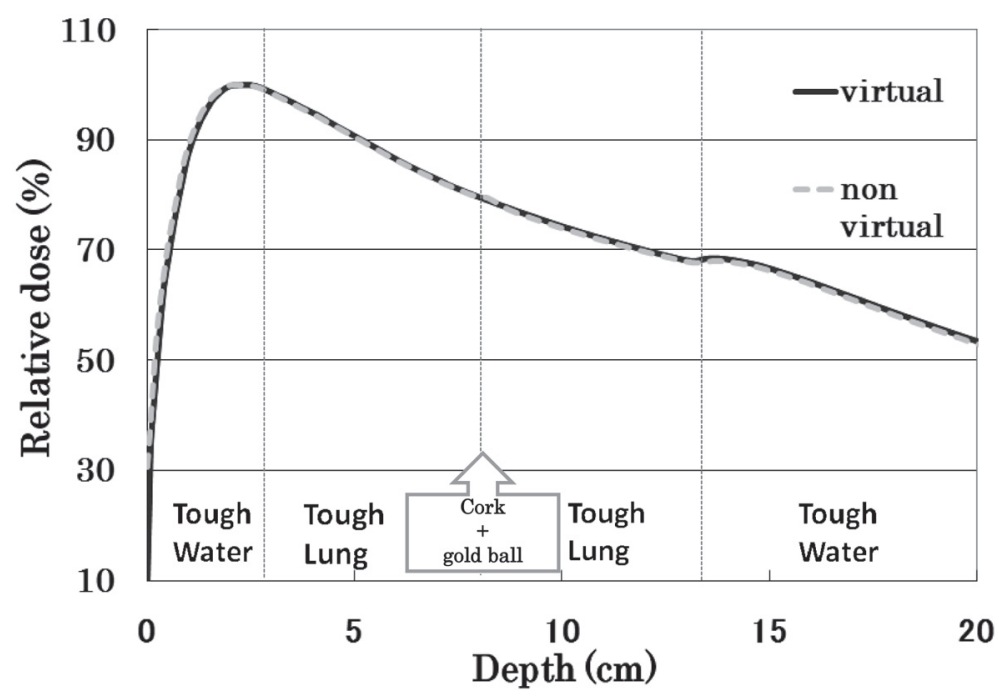

Fig. 6 Comparison of the relative dose distributions between the virtual phantom (model 1) and non-virtual phantom calculated using the superposition algorithm.

を比較したものを Fig. 7，8 に示す.ビーム軸に対し て平行な方向の時と同様に深さ $5 \mathrm{~cm}$ で EBTを基準 として相対線量化を行った. Fig. 7 を見ると, 金球付 近において中心軸から $\pm 0.5 \mathrm{~cm}$ 以内で EBT と EGS5 で線量の増加が見られたが，XiOでは線量の増加が 見られなかった. Fig. 8 においても金球付近において
EBT と EGS5 で線量の減少が見られたが，XiOでは 線量の減少は見られなかった。さらにEGS5 の中心 部のボクセルをより細かく分割して計算した Fig. 9, 10 の結果を見ると, EGS5 と EBTの值がより近づく 傾向が見られた。 


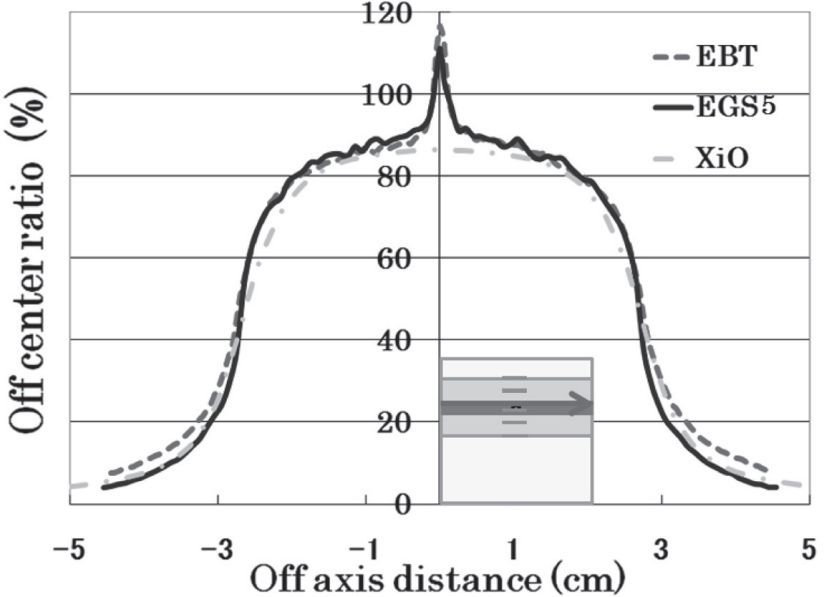

Fig. 7 Comparison among film measurement (EBT), the MC simulation (EGS5), and RTPS calculation (XiO) at the incident side of the gold $(8 \mathrm{~cm}$ depth).

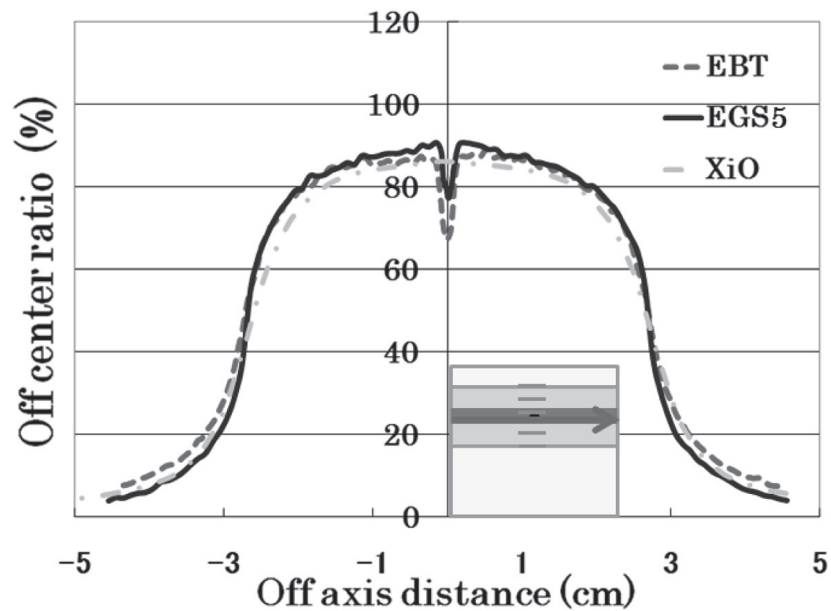

Fig. 8 Comparison among film measurement (EBT), the MC simulation (EGS5), and RTPS calculation (XiO) on the exit side of the gold $(8.2 \mathrm{~cm}$ depth).

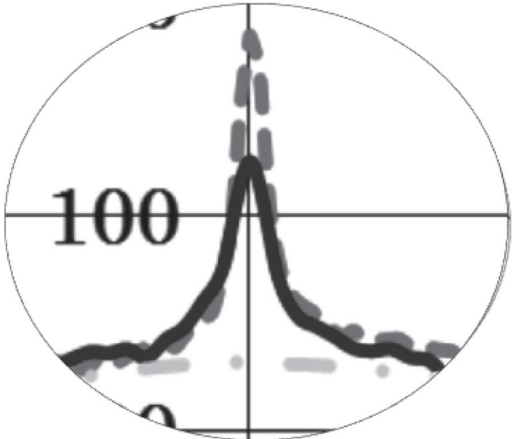

$\stackrel{\mathrm{x}}{\stackrel{\mathrm{y}}{\longrightarrow}}$

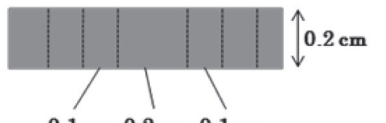

$0.1 \mathrm{~cm} 0.2 \mathrm{~cm} 0.1 \mathrm{~cm}$
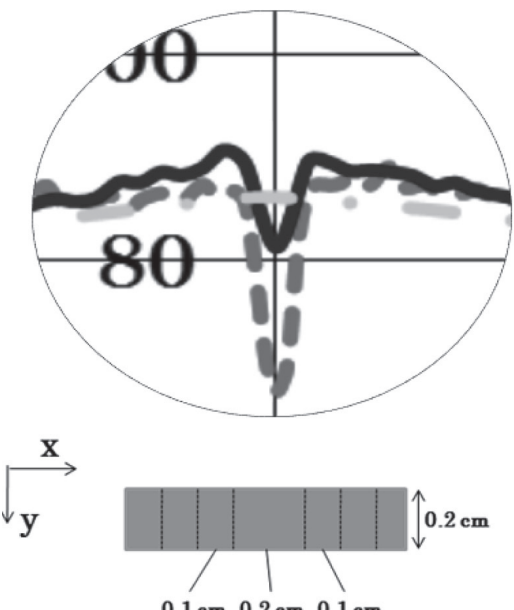

$0.1 \mathrm{~cm} 0.2 \mathrm{~cm} 0.1 \mathrm{~cm}$
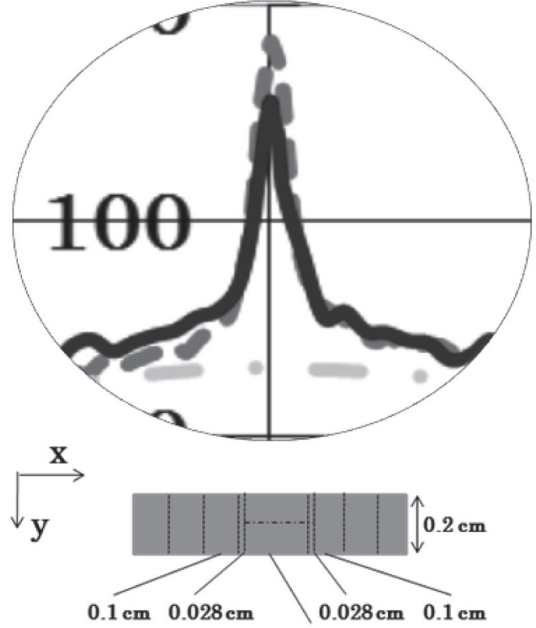
$0.016 \mathrm{~cm}$ interval
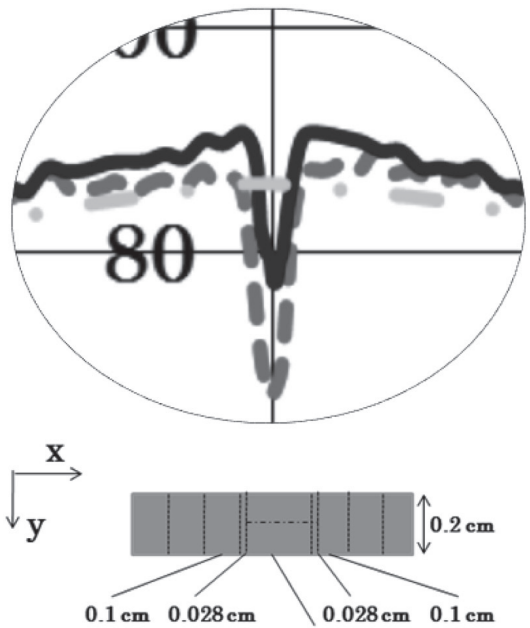

$0.016 \mathrm{~cm}$ interval a $\mid \mathrm{b}$

Fig. 9 Comparison of Monte Carlo dose profiles that arose from the partial volume effect (8 $\mathrm{cm}$ depth).

(a) Before subdivisions of the central voxel

(b) After subdivisions of the central voxel $a \mid b$

Fig. 10 Comparison of Monte Carlo dose profiles that arose from the partial volume effect $(8.2 \mathrm{~cm}$ depth).

(a) Before subdivisions of the central voxel

(b) After subdivisions of the centra voxel 


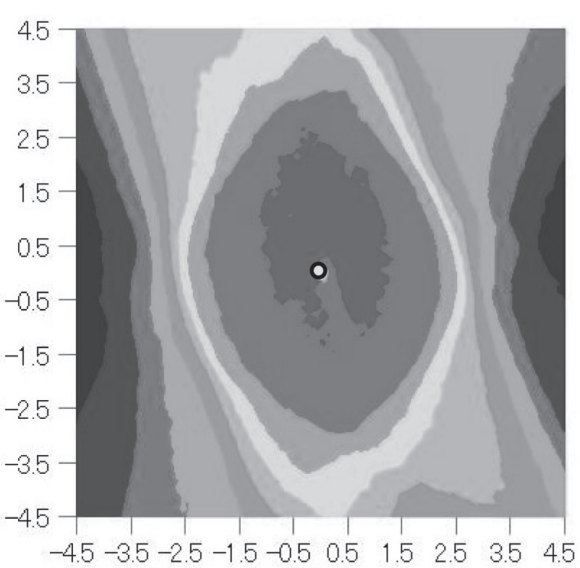

Distance from the center of axis $(\mathrm{cm})$ EGS5

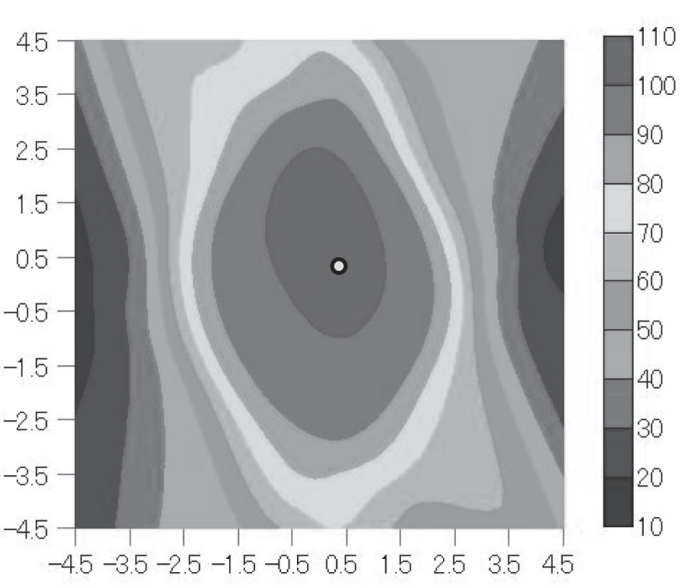

Distance from the center of axis $(\mathrm{cm})$

XiO

Fig. 11 Comparison of the relative dose distribution between the MC simulation (EGS5) and RTPS calculation (XiO) at the isocenter plane.

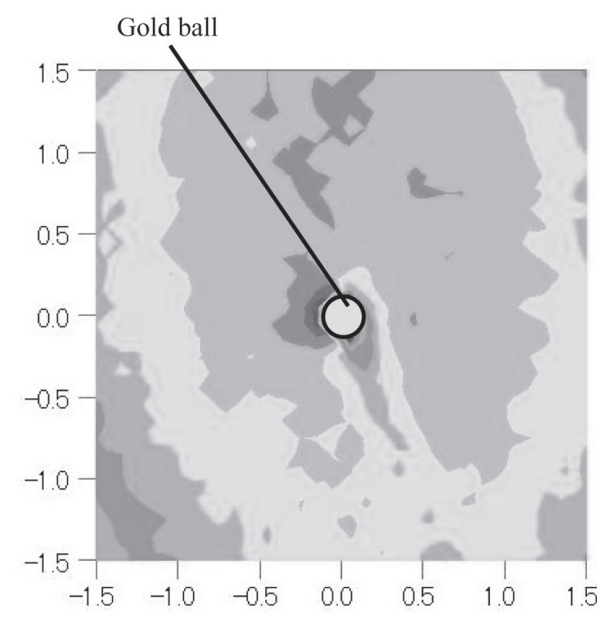

Distance from the center of axis $(\mathrm{cm})$

EGS5

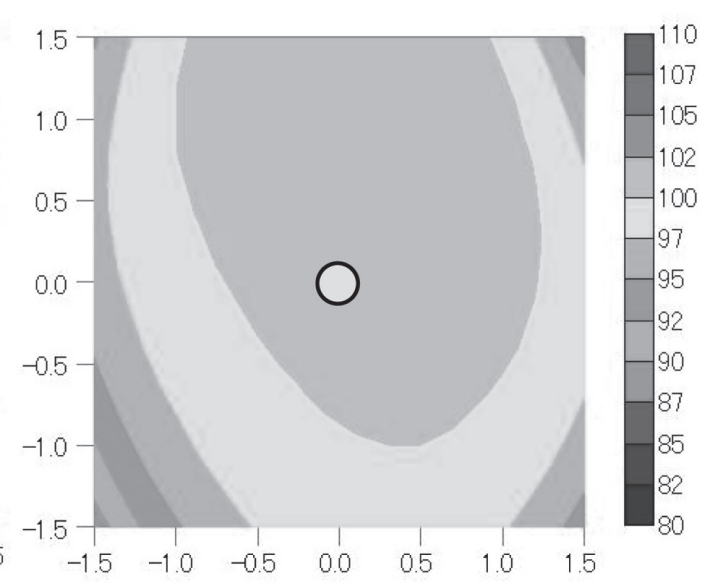

Distance from the center of axis $(\mathrm{cm})$

\section{$\mathrm{XiO}$}

Fig. 12 Comparison of the relative dose distribution between the MC simulation (EGS5) and RTPS calculation (XiO) at the isocenter plane (partial enlarged view).

2-2 肺野内における金マーカの線量分布への影響 : 8 ビーム

\section{2-2-1 シミュレーション結果の比較}

本研究では EGS5 と XiO の計算結果を比較するた め, 各深さにおける照射野内の平坦化領域で EGS5 を基準として相対線量化を行った。深さ $0 \mathrm{~cm}$ での計 算結果の比較を Fig. 11 に示す. EGS5 と XiO は金球 付近を除いてよい一致が見られた。中心部を拡大し たものをFig. 12 に示す。また，各深さにおけるプロ ファイルを比較したものを Fig. 13 に示す. EGS5 にお いて金球付近で散乱線による線量の増加, 減少が見

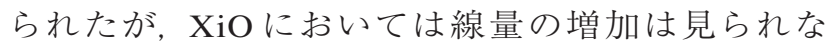

かった. EGS5 では $0.15 \mathrm{~cm}$ 深で最大 $110.3 \%$ の線量 増加領域が見られ， $-0.15 \mathrm{~cm}$ 深でも $109.3 \%$ の線量増 加領域が見られた。

\section{3. 考 察}

金球付近において EGS5 と EBT で差異が生じた原 因のひとつにパーシャルボリューム効果による影響が 考えられる。結果でも述べたように Fig. 9，10を見る と, EGS5 の中心部のボクセルサイズをさらに細かく 分割して計算したことでEGS5 と EBT の差異が小さ くなったことが分かる。これは方法でも述べたように

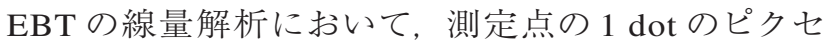



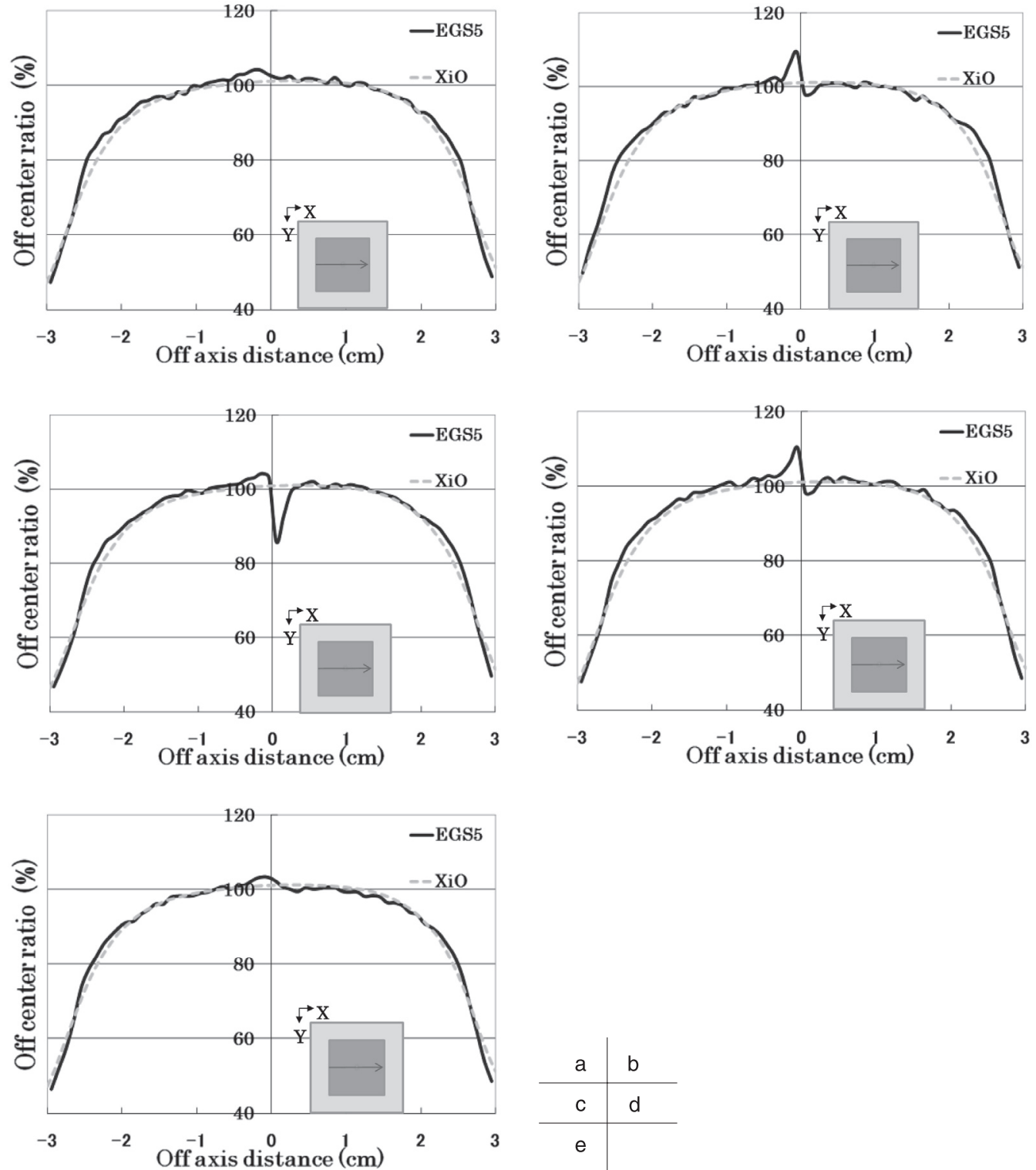

Fig. 13 Comparison of the relative dose profiles between the MC simulation (EGS5) and RTPS calculation $(\mathrm{XiO})$.
(a) $-0.25 \mathrm{~cm}$ depth
(b) $-0.15 \mathrm{~cm}$ depth
(c) $0 \mathrm{~cm}$ depth
(d) $+0.15 \mathrm{~cm}$ depth
(e) $+0.25 \mathrm{~cm}$

ルサイズが $0.017 \mathrm{~cm}$ で行われているのに対し，EGS5 ではデータ取得領域のボクセル内の平均值を算出す るため, パーシャルボリューム効果により金マーカ付 近の急峻な線量変化の鋭さが失われて計算され,

EGS5 とEBT で差異が生じたと考えられる。ほかの 原因として，EBTを用いた実測では一回のみの測定 のため, EBT の感度のばらつきによる $5 \%$ 程度の線 量誤差が考えられるほか, EBTとファントムの圧着 不足によって実測とシミュレーションのジオメトリが 若干異なり, 結果として誤差が生じた可能性が考え られる。

金球付近で XiO と EGS5 の計算結果に差が生じた
のは，XiO が後方散乱，前方散乱，側方散乱などによ る線量増加, 線量減少を正しく計算できていないた めであると考えられる。この RTPS の線量計算アルゴ リズムの限界については Siarhei ら ${ }^{3)}$ と Shimozato ら ${ }^{4)}$ の研究でも報告されている，基本的に Superposition では，水のカーネルを基に密度だけを変えており，原 子番号の変化は考慮していないため, 金属としての 線量分布の複雑な変化は計算できないと考えられ る.よって一方向からの照射プランにおいて, RTPS による計算では金マーカ付近の計算精度が低いた め, 金マーカ付近で過剒線量, あるいは過小線量が 投与される可能性がある. 
$\mathrm{XiO}$ の計算において virtual phantom と non virtual phantomの計算結果が全体的によく一致し，金属 アーチファクトによる影響が見られなかったことにつ いては, CT 值 - 相対電子密度変換テーブルと CT 值 の平均化による影響を受けたものであると考えられ る. Fig. 2 を見ると金球付近に CT 值の低いアーチ ファクトと CT 值の高いアーチファクトが見られる.

CT 值の低いアーチファクトの相対電子密度を調べる と CT 值 - 相対電子密度変換テーブルの下限である 0.3 であった。すなわち肺野と同じ相対電子密度で あったことから CT 值の低いアーチファクトの影響を 受けなかったと考えられる。また CT 值の高いアーチ ファクトについて，橘らはノイズの影響で CT 值の変 動があった場合，CT 值が平均され， RTPS では影響 が少ないという報告をしている99. 今回 CT 值の高い アーチファクトの広がりは少なく, CT 值が平均化さ れたことによってアーチファクトの影響が少なかった のではないかと考えられる。 さらに, virtual phantom で金球の相対電子密度を 14.0 に設定しても non virtual phantom とほとんど差異が見られなかったことから，

RTPS の線量計算アルゴリズムの限界による影響を受 けた可能性がある.

Fig. 11，12に示されるように多方向からの照射プ ランにおいても金球付近で XiO と EGS5 の計算結果 に差が生じた。この結果から金マーカを埋め込む場 合，XiOの計算では金マーカ付近の計算精度が低い ため, 実際の線量を過大評価あるいは過小評価する 可能性がある。さらに臨床においては, 腫瘍の位置 をより高精度に同定するために金マーカを 3 個程度 用いる場合が多いので，XiOの計算精度を考慮した 上で腫瘍組織への投与線量を決定する必要があると 考えられる. 特に Fig. 15 の EGS5 の計算結果を見る と, 深さ $0 \mathrm{~cm}$ における照射野内の平坦化領域に対し て $85.8 \%$ の線量減少領域が見られたが，もしこの線 量減少領域に腫瘍が位置していた場合，腫瘍への投 与線量不足につながりかねない，そのため，金マ一 カによる散乱線の影響が比較的少ない距離まで金 マーカと腫瘍との間を保ったほうが良いと考えられ る. 適切な距離については金マーカの大きさによって 変化するが, $10 \mathrm{MV}$ の X 線で 1 門照射の場合, 金
マーカによる散乱線の影響が少ない $0.5 \mathrm{~cm}$ 以上の距 離を保つべきである。ほかのエネルギーに関しては今 後の検討課題とする. 多門照射の場合は 1 門照射と は異なり，金球付近における散乱線の影響がより少 ないと考えられるが, 入射角度や各門の線量加重の 条件によって影響が異なるため, 適切な距離につい て現時点では $0.5 \mathrm{~cm}$ 以上の距離を保てば問題ないと 考えられる。

\section{4. 結 語}

本研究ではフィルム法による実測, モンテカルロ計 算, RTPSを用いて相対線量分布を取得し, 比較を 行うことで金マーカからの散乱線による人体への影 響を検討した。その結果，フィルム法による実測，モ ンテカルロ計算によって金球付近で散乱線による線 量増加, 線量減少を確認した。一方で, RTPSでは 金球付近での後方散乱, 前方散乱, 側方散乱などに よる線量増加, 線量減少を正しく計算できていないこ とが推測された、今回の結果から RTPS による計算 では金マーカ付近で過剰線量, あるいは過小線量を 投与する可能性がある。また，金マーカからの散乱 線によって金マーカ付近で線量増加, 線量減少が生 じるため, 腫瘍組織への線量不足やリスク臓器への 線量増加が懸念される。したがって, 金マーカによる 線量の乱れを除外するために, 金マーカと腫瘍との 間の距離を $0.5 \mathrm{~cm}$ 以上離すべきである.

\section{謝 辞}

本研究の遂行にあたり, 御協力ならびに御助言を いただきました名古屋第二赤十字病院 大島隆嗣 氏, 名古屋市健康福祉局 柴田洋希氏, 論文作成に 際しご助言いただきました名古屋大学名誉教授 田 伏勝義先生ならびに名古屋大学医学部保健学科准教 授 小森雅孝先生, その他関係者の皆様に深く感謝 致します.

なお本研究の要旨は, 第 65 回日本放射線技術学 会学術大会 (横浜, 2009 年), 第 16 回 EGS 研究会 (つくば，2009年), 第 52 回米国放射線腫瘍学会 (サ ンディエゴ, 2010 年)にて発表した. 


\section{参考文献}

1) Leksell L. The stereotaxic method and radiosurgery of the brain. Acta Chir Scand 1951; 102: 316-319.

2) Shirato H, Harada T, Harabayashi T, et al. Feasibility of insertion/implantation of 2.0-mm-diameter gold internal fiducial markers for precise setup and real-time tumor tracking in radiotherapy. Int J Radiat Oncol Biol Phys 2003; 56(1): 240-247.

3) Spirydovich S, Papiez L, Langer M, et al. High density materials and radiotherapy planning: comparison of the dose predictions using superposition algorithm and fluence map Monte Carlo method with radiochromic film measurements. Radiother Oncol 2006; 81(3): 309-314.

4) Shimozato T, Yasui K, Kawanami R, et al. Dose distribution near thin titanium plate for skull fixation irradiated by a 4-MV photon beam. J Med Phys 2010; 35(2): 81-87.

5) 宮沢正則 . ガフクロミックフィルムを用いた線量分布測定
法. 日放技学誌 2006; 62(10): 1428-1436.

6) Menegotti L, Delana A. Radiochromic film dosimetry with flatbed scanners: a fast and accurate method for dose calibration and uniformity correction with single film exposure. Med Phys 2008; 35(7): 3078-3085.

7) Sheikh-Bagheri D, Rogers DW. Monte Carlo calculation of nine megavoltage photon beam spectra using the BEAM code. Med Phys 2002; 29(3): 391-402.

8) McCullough EC, Holmes TW. Acceptance testing computerized radiation therapy treatment planning systems: direct utilization of CT scan data. Med Phys 1985; 12(2): 237-242.

9）橘 昌幸，木下絵美，平田敬子．治療計画装置使用時に おける最適 X 線 CT 画像の検討一画像ノイズ，スライス 厚について一. 日放技学誌 2004; 60(4): 507-512.

\section{| | | | | | | | | | | | | | | | | | | | | | | | | | | | | | | | | | | | | | | | | | | | | | | | | | | | | | | | | 図表の説明 || |}

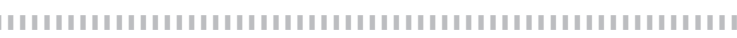

Fig. 1 仮想肺ファントムの概略

Fig. 2 Superposition 法によって計算された線量分布図

Fig. 3 （a） 8 方向照射プランに抢ける仮想肺ファントムの概略 $(x z$ 平面 $)$

(b) 8 方向照射プランにおける仮想肺ファントムの概略 $(x y$ 平面)

Fig. 4 線量対濃度の校正曲線

Fig. 5 ビーム軸に対して平行な方向における実測(EBT), モンテカルロシミュレーション (EGS5), 治療計画装置 $(\mathrm{XiO})$ の比較

Fig. $6 \mathrm{XiO}$ 上において仮想的に作成した肺ファントムで計算された相対線量分布と CT 撮影で得られた肺ファントム画像で計算 された相対線量分布の比較

Fig. 7 金球透過直前の深さ $(8 \mathrm{~cm}$ 深)に抢ける実測 $(\mathrm{EBT})$, モンテカルロシミュレーション $(\mathrm{EGS} 5)$, 治療計画装置 $(\mathrm{XiO})$ の比較

Fig. 8 金球透過直後の深さ $(8.2 \mathrm{~cm}$ 深)に扔ける実測 $(\mathrm{EBT})$, モンテカルロシミュレーション $(\mathrm{EGS5})$, 治療計画装置 $(\mathrm{XiO})$ の比較

Fig. 9 パーシャルボリウム効果による影響 $(8 \mathrm{~cm}$ 深 $)$
(a) 中心部ボクセルの細分割前

（b）中心部ボクセルの細分割後

Fig. 10 パーシャルボリウム効果による影響 $(8.2 \mathrm{~cm}$ 深 $)$
(a) 中心部ボクセルの細分割前

（b）中心部ボクセルの細分割後

Fig. 11 アイソセンタ平面に扮けるモンテカルロシミュレーション(EGS5), 治療計画装置 $(\mathrm{XiO})$ の相対線量分布の比較

Fig. 12 アイソセンタ平面に証けるモンテカルロシミュレーション(EGS5), 治療計画装置 $(\mathrm{XiO})$ の相対線量分布の比較(拡大図)

Fig. 13 各深さに扔けるモンテカルロシミュレーション(EGS5), 治療計画装置 $(\mathrm{XiO})$ の)線量プロファイルの比較

Table 1 仮想肺ファントムの構成

Table 2 それぞれの深さにおいて EBT を基準としたときの EGS5 と XiO の䛊差率 